\title{
電波流速計による洪水流量観測
}

\section{山口高志*・新里邦生 ${ }^{* *}$}

\begin{abstract}
電波流速計は、橋上等から河川水面に向かって電波を発射し，その反射を受信し，ドッ プラー効果を利用して表面流速を求めるものである. 本論は, 2 年にわたる融雪出水期 を利用した現地観測等により, 数点の表面流速值から相当の精度で流量を求めることが 可能なこと, 流向観測が可能なこと, $H \sim Q$ のループ特性把握に有効なことなどがわ かった.

Key Words : radio current-meter, surface velocity, flood discharge observation, $H \sim Q$ loop, velocity vector
\end{abstract}

\section{1. 目的および経緯}

本論では，電波流速計を用いた洪水流量観測法につい て現地調査を主体に検討した結果を報告する。

河川での洪水流量観測は, 他に適当な方法がないこと もあって, 長年にわたって棒浮子観測が，実施されて来 た.これは，プライス等に代表される回転式流速計，あ るいは電磁式流速計も含めて, 水流の強さ, あるいはゴ ミ等のために, 洪水中に長期にわたって設置できないこ とによっている.

しかし，浮子観測についても，投下後いつも同じ経路 を流れるとは限らないことが大きな欠点である．流量観 測は, 通常橋梁下流で行われるが, ピア一の後流域は, 相当長く, 浮子がこの後流域に入ると, 測定に影響を及 ぼす。これは, 河岸付近についても, 浮子が逆流するな よ゙，実際に経験するところである．また，木下氏は，い つも浮子が流心を流れ, 流量を過大評価すると指摘して いる1).

さらに浮子は，観測員が投下することから，現場到着 がおくれるため, 洪水途中からしか観測できない, ある いはピークを取り逃す, 橋梁が危険になると中止して撤 退する，など有効なデータの取得に問題がある. また， テレメータ化されている雨量, 水位に比して, すぐにオ ンラインデータにならないことも, 前近代的といえる.

これまでに洪水流量観測を試みた例として，まず木下 良作氏の航測を用いて, カメロン効果を利用した表面流 速分布観測が有名であるが11,2)，いつも航空機がとべる か, という問題がネックになる. 加えてデー夕処理を必 要とするため, オンラインデータ化は今後の課題といえ

\footnotetext{
* 正会員 工博 東京電機大学建設工学科、前 (財) 河川情報 センター河川情報研究所

( =350-03 埼玉県比企郡鳩山町石坂)

**正会員 横河ウェザック (株)
}

る. 河川横断方向に設置されて, 横断方向の平均流速を 観測する超音波流速計 ${ }^{31} も ，$ 低水，平水には，偉力を発 揮するが, 洪水になって浮遊物質濃度が大きくなると, 音波は反射散乱されて, 対岸にとどかず, 観測不能になっ てしまう.あまり洪水向きとはいえない.

ほかに，河床底面から気泡を発生させ，この気泡が水 深方向すべての点の流速の影響を受けて水面に達するこ とから, その流下距離より流速を求める方法がある+1. 低・平水時には, 有効と考えられるが, 洪水時には気泡 の追跡に一工夫必要と考えられる.

このように考えて来ると, やはり, 水中に観測機器を いれて測定する方法は, 現状では無理なことが推測され る.すなわち非接触な手法にたよらざるをえないと考え られる。

非接触な方法というと，おのずと水表面から情報をと るということになるが，1つの方法として，水中からの 渦の湧きあがりの移動に着目し, これを撮影, 画像処理 により流速を出そうというものがある5 ${ }^{5}$. 方法論的には 有効と考えられるが, 浮遊砂の少ない河川, あるいは, 河币の大きな河川の観測方法などが原因と思われるが, 実用化には到っていない。

電波流速計は，同様に非接触で，橋上等から，河川水 面に電波を発射し，その反射を受けて，ドップラ一周波 数により，表面流速を測定するものである．相当正確に 表面流速をとらえていることは用水路などを使って確か められているが, 情報量が表面流速だけというところに ネックがあり, 最近までは, あまり河川で用いられてい なかった。

電波流速計は, どうしても非接触でなければならない 砂防の分野で, 15 年ほど前から, 同じ非接触の超音波 水位計と併用されて利用され始めている.

本報では，電波流速計を洪水流量観測用に利用するべ く, 表面流速からの流量算出法について, 現地観測デー 


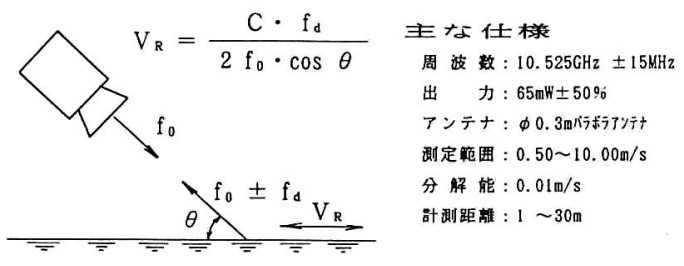

図一1 测定原理

表一1 表面浮子との検証

\begin{tabular}{|l|c|c|c|c|}
\hline & 1 回目 & 2 回目 & 平 均 & 流 速 \\
\hline \hline 表面浮子 & $\begin{array}{l}15.41 \mathrm{sec} \\
(3.24 \mathrm{~m} / \mathrm{s})\end{array}$ & $\begin{array}{l}15.75 \mathrm{sec} \\
(3.17 \mathrm{~m} / \mathrm{s})\end{array}$ & $\begin{array}{l}15.58 \mathrm{sec} \\
(3.21 \mathrm{~m} / \mathrm{s})\end{array}$ & $3.21 \mathrm{~m} / \mathrm{s}$ \\
\hline 電波流速計 & $3.23 \mathrm{~m} / \mathrm{s}$ & & & $3.23 \mathrm{~m} / \mathrm{s}$ \\
\hline
\end{tabular}

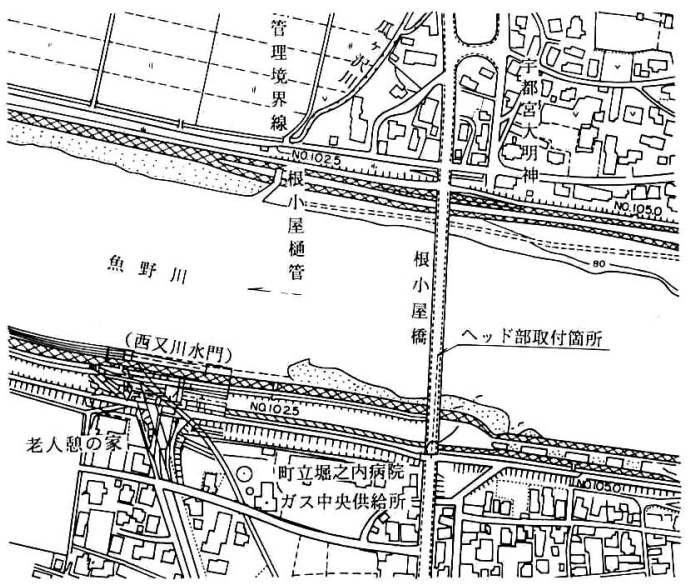

図一2 魚野川堀之内地点平面図

夕をもとに検討を行った結果を報告する。また，電波流 速計の効用，火点等についてもまとめておく.

\section{2. 理論的根拠}

電波流速計の理論的根拠は, 警察のスピード違反の取 締まりと同じ原理で，電波によるドップラ一周波数を用 いた表面流速測定である。具体には，橋梁等上り俯角を もって電波を発射し，水面上の波加の反射を受け，そ の点の表面流速を測定するものである（図一 $1, V_{R}$ : 表 面流速, $C$ : 電波伝播速度, $f_{d}$ : ドップラ一周波数, $f_{0}$ : 発信周波数, $\theta$ : 俯角). 当初は, 水分子の粒子速度 と表面波の進行速度のどちらを測っているか，相当疑念 があったのであるが，実測を重ねるうちに，前者を測っ ていることに確信がついて来た，参考までに 1 例：大井 川の用水路でのデータを表一1に示す。

ただし，流速が小さく水面に波がないような場合には 電波の反射がないためにデータがとれない。一般的にい えば表面流速が $50 \mathrm{~cm} / \mathrm{s}$ 以下では, 観測不能になる.

参考までに電波流速計は, $10 \mathrm{GHz}$ という波長の短い

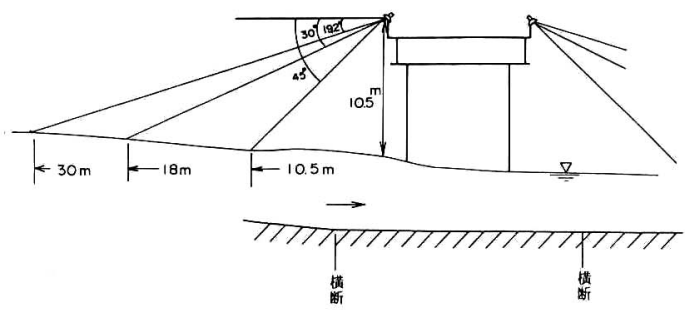

図一3 観測方法概念図

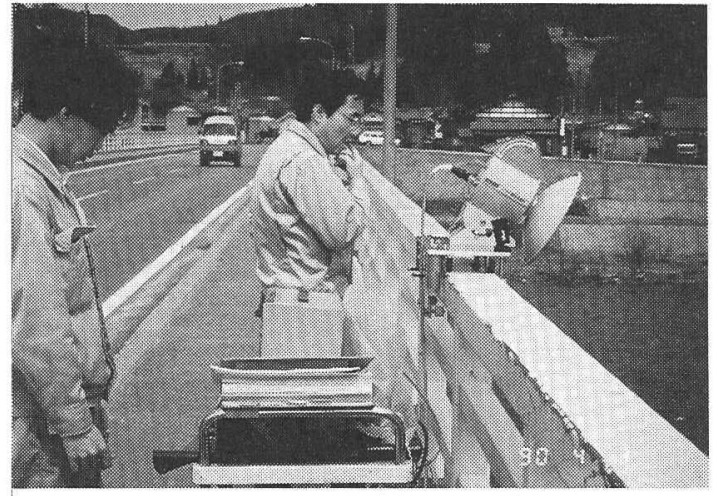

写真一1 電波流速計による観測

電波を使用しているので，降雨（雪）よりの反射電波を 受ける. 事実データの取得に障害之なった経験もある. しかし最近では，調整することによってあまり影響を受 けないようになっている。

\section{3. 現地観測の経緯と結果}

\section{（1）経緯および解析対象データ}

信濃川水系魚野川堀之内地点（根小屋橋）では, 1988 年 3 月から電波流速計が 1 基設置され観測を開始した

(図一2, 横断図は図一10参照)。そのデータの活用を はかるべく, 3 月〜4 月の融雪出水を利用した現地調查 が，1990９1 年にわたって実施された.

1990 年は, 電波流速計がドップラー効果を利用して いるので，上下流方向どちらでも計測できることから， 上下流両方での観測, 加えて俯角を $45^{\circ}, 30^{\circ}, 19.2^{\circ}$ 之 変えた場合，“および橋が $10^{\circ}$ ほどスキューであることか ら，偏角を変えての観測（橋に直角方向および河川法線 に平行な場合)など，バラエティをもって観測を実施し た（延べ 7 日間，40 ケース).

観測の具体は，河幅約 $150 \mathrm{~m}$ に対して，橋上に $5 \mathrm{~m}$ 問隔に測点を設け, 約 30 点で, 可搬式電波流速計を欄 干上を移動させながら表面流速の横断分布の観測を行っ た (図一 3 , 写真一 1 ). 橋の高欄高が水面から約 $10 \mathrm{~m}$ なので, $45^{\circ}$ の場合 $10 \mathrm{~m}$ 前（後）方の表面流速を測定 していることになる.

1991 年の融雪出水時は, 前年度の調査結果をうけて 


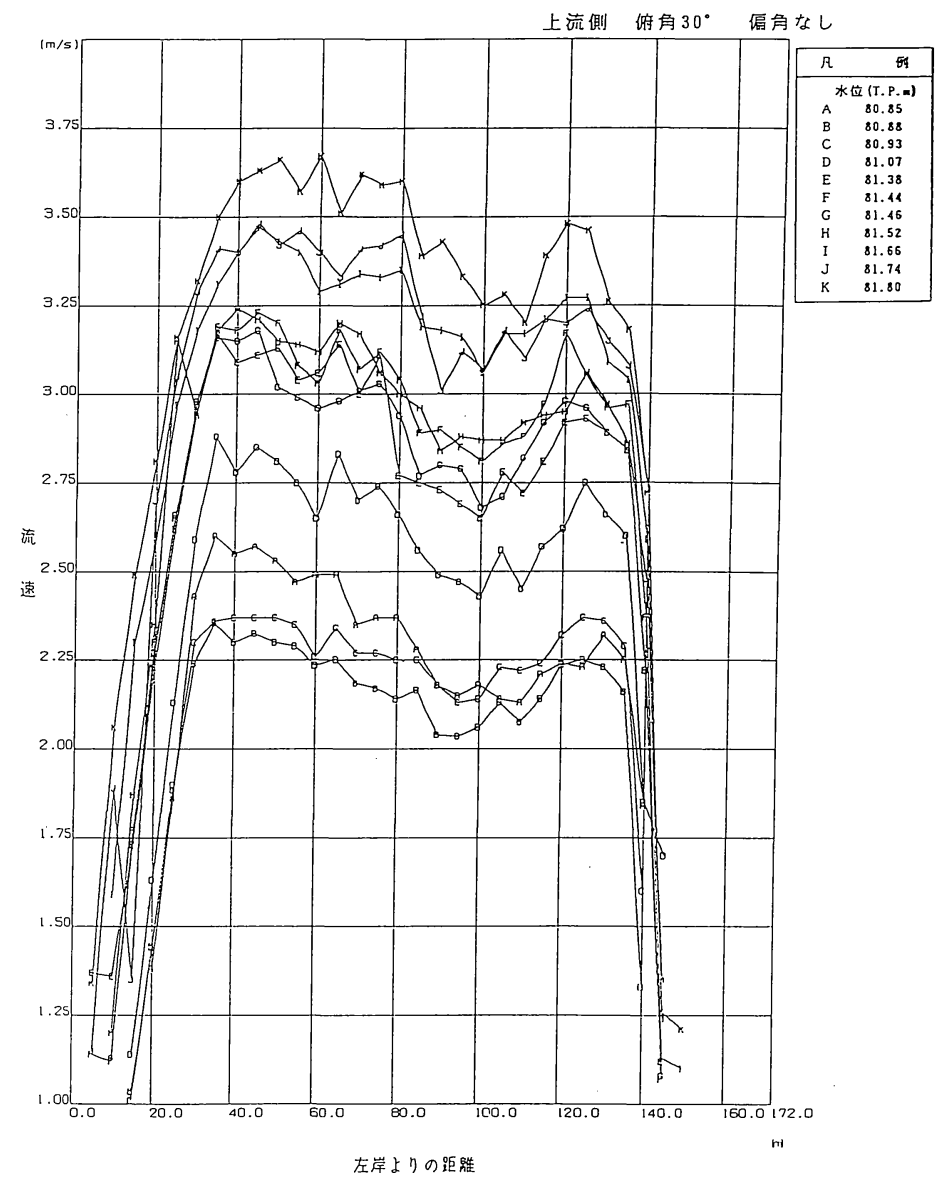

図一4 横断流速分布図

根小屋橋に電波流速計が 4 基追加されたので(都合 5 基, 上流向け俯角 $30^{\circ}$, 偏角 $10^{\circ}$ ), 調查の重点を, 上流側俯 角 $30^{\circ}$ に移し，同様の調查を行った.

90 91 年にわたる横断方向表面流速分布調查は, 延 ベ 11 日間，53 ケースにわたる。また，上流向け， $30^{\circ}$ の観測ケースは，11 ケースとなった，本報告は，主に この 11 ケースの結果の解析ということになるが，この 他，水面 1 点を橋上 2 ないし 3 点から，観測した流速べ クトル調査, 都市河川下流での $H \sim V$ のープ特性の観 測事実等についても報告したい。

なお観測は，横断方向 30 点の観測を，平均して 30 分 （1 点移動を含めて 1 分）かけて実施したが, 融雪出水 は, 相対として定常性が強 $<$, 水位変化は $0 \sim 6 \mathrm{~cm} / 30$ 分がほとんどで，それほぼデータの同時性については， 気にならないと考えている.

\section{（2）観測結果}

結果の 1 例として 2 年間 53 ケースの横断表面流速分 布から, 前述のように上流向け俯角 $30^{\circ}$ のもの 11 ケ一 スを選び図示する（図一4）。水位序列に対する，流速分
布の大きさの序列の関係は, $A$ が $B, C$ 上り大きい, $F$ が $G$ より少し大きい，なぜ一部矛盾があるが，水位測 定が量水標で目視していることもあって, 全体としては, ほぼ妥当な結果と言えよう。

図一4は, 橋上よりわれわれが観測した結果であるが, それとは別に橋梁のガーダーに電波流速計が 4 台, 左岸 から $15 \mathrm{~m}, 45 \mathrm{~m}$ (ほぼ流心)，90 m, $135 \mathrm{~m}$ の位置に据 えつけてあり (その順に測点 1 4), これらは, 5 分毎 に連続的にデー夕をとっている. 91 年度融雪出水期 3 月〜 5 月の毎時デー夕を，水位をパラメータにしてプ ロットすると, 図一 5 が得られる. 測点毎に固有の変化 をすること，ほとんどの部分で， $\Delta V=15 \mathrm{~cm} / \mathrm{s}$ の幅の 中に入ること $(V=3 \mathrm{~m} / \mathrm{s}$ とすると, 誤差は $5 \%$ 以下 $)$, 測点 3 が，水位上昇とともに測点 4 を追い抜くこと，な ビが読み取れる。とくにこの部分では，測点 3 の上昇が シャープで, 測点 4 が鈍化しており, 大きな流況の変化 が推定できる，すなわち，測点 3 は，川の中央部にあた り. (図一10 横断図参照), 右岸の流れが強かったのが水 位の上昇とともに, 中央部の直進性が強くなったものと 


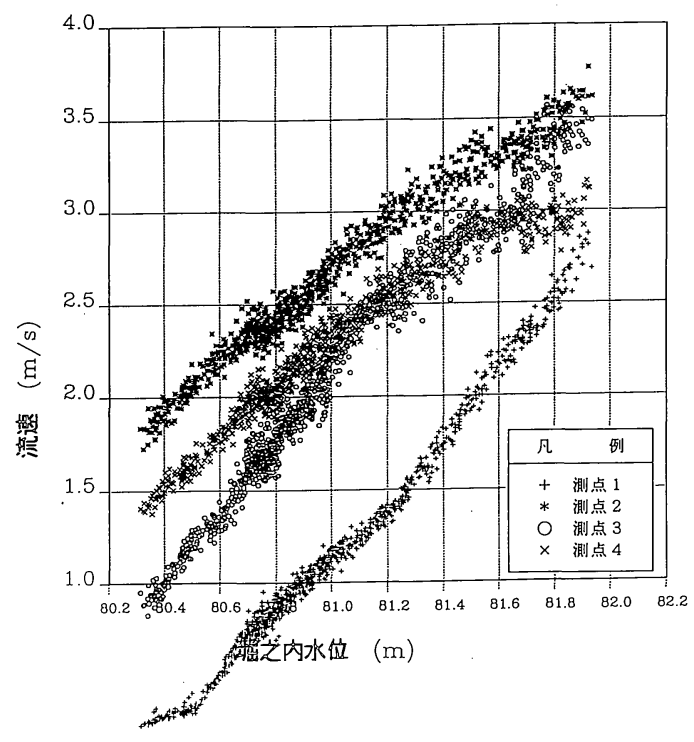

図一5 現地 $H \sim V(3$ 月 15 日 $~ 5$ 月 18 日)

思われる.しかし，この水位までではまだ測点 2 (左岸) が最大である.

\section{4. 観測結果の解析}

\section{(1) 流量換算係数}

流量換算係数を以下のように定義する.

$Q=f_{v} \sum^{30} V_{s i} \Delta A_{i}$

$f_{v}:$ わば表面流速と鉛直方向平均流速との換算係 数

$V_{s i}: 5 \mathrm{~m}$ 毎に観測した表面流速, $\Delta A_{i}=\Delta B \times h_{i}$

$$
\Delta B=5 \mathrm{~m} \text {, }
$$

$h:$ 水深, 次に

$$
\sum_{i}^{30} V_{s i} \Delta A_{i}=f_{H} \sum_{j}^{1-4} V_{s j} A_{j}
$$

$f_{H}$ : 横断方向数点の表面流速を用いて算出される流

量と，30 点すべてを用いて算出される流量と の比

$V_{s j}: 30$ 点の表面流速測定值の中から, 固定測点で の測定值 1 ないし 4 をえらんだもの

$A_{j}: 1$ ないし 4 点それぞれが代表しうる断面積ただ ᄂ $A_{j}=n \Delta A_{i}(n=2 \sim 30)$

$$
\begin{aligned}
Q & =f_{v} \cdot f_{H} \cdot \sum_{j}^{1-4} V_{s j} A_{j} \\
& =f \sum_{j}^{1-4} V_{s j} A_{j} \ldots \ldots
\end{aligned}
$$

すなわち

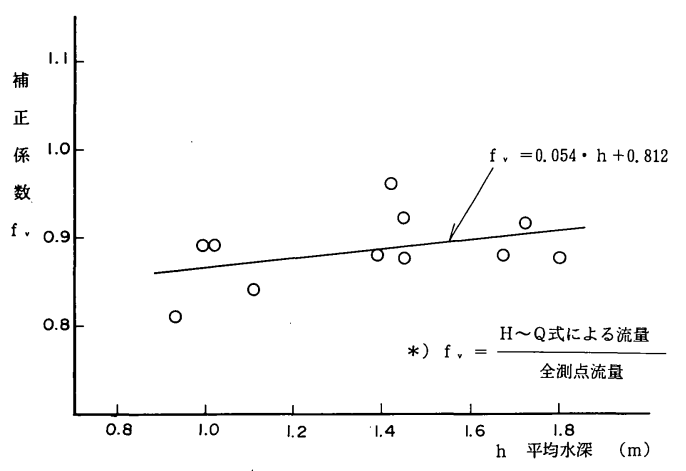

*) $\overline{f_{\mathrm{v}}}=0.885$

図-6 $h-f_{v}$

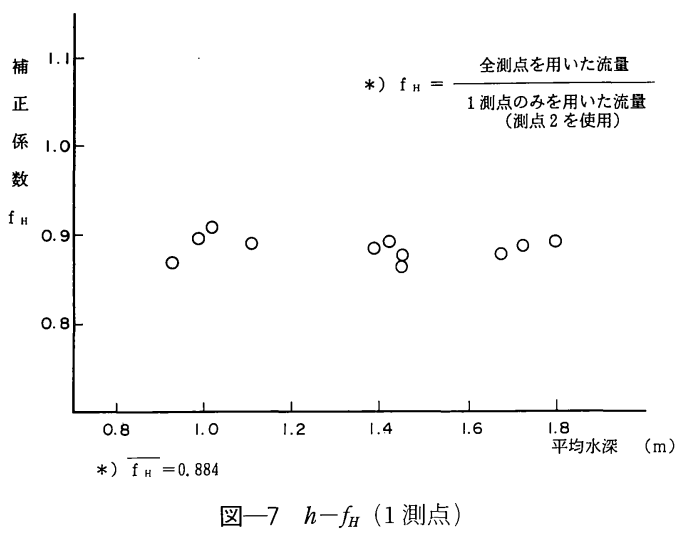

$$
\left.\begin{array}{l}
f_{v}=\frac{Q}{\sum^{30}}, f_{H}=\frac{\sum^{30}}{\sum^{1-4}} \\
f=\frac{Q}{\sum}, f=f_{v} \cdot f_{H}
\end{array}\right\}
$$

となる、新たに, 洪水流量観測システムを設置する場合 には, 通常数点しか設置しないのでこの $f$ が重要となる.

これらの換算係数の特性を, 11 ケースの横断方向流 速分布の観測值 (図一4) 加 $\sum^{1-4}, \sum^{30}$ 等を算出し, 流 量 $Q$ については，信濃川堀の内の $H \sim Q$ カーブを用い て分析する. なお， $\sum^{1-4}$ の算出も 30 点の流速分布の観測 値を利用し，橋梁に設置された流速計の值は検証用にの み利用する。

$f_{v}: f_{v}$ を 11 ケースについて算出, $h=A / B$ によって整理 したところ，図一6を得た，少しばらついているが，平 均值 $f_{v}=0.885$, 水深の増加とともにわずかに増加する. 通常 $\bar{V} / V_{s}=0.85$ 亡いわれていること和ら，これはほ ぼ妥当の值といえよう.

他に，対数流速分布式 ${ }^{71} よ り$

$$
\frac{\bar{V}}{V_{s}}=\frac{6.0+5.75 \log _{10}\left(h / K_{s}\right)}{8.5+5.75 \log _{10}\left(h / K_{s}\right)}
$$

が得られるが, 適当な数値を代入して表一2が得られる. 


\begin{tabular}{|c|c|c|c|c|}
\hline \multicolumn{5}{|c|}{ 表一2 $\bar{V} / V_{s}$ (式 5) } \\
\hline & $\mathrm{h}=1^{\mathrm{m}}$ & $\mathrm{h}=2^{\mathrm{m}}$ & $\mathrm{h}=2.5^{\mathrm{m}}$ & $h=5^{m}$ \\
\hline$K_{s}=0.05^{\mathrm{m}}$ & 0.844 & 0.859 & 0.863 & 0.875 \\
\hline$K_{s}=0.1$ & 0.825 & 0.844 & 0.849 & 0.863 \\
\hline$K_{s}=0.2$ & 0.800 & 0.825 & 0.831 & \\
\hline
\end{tabular}

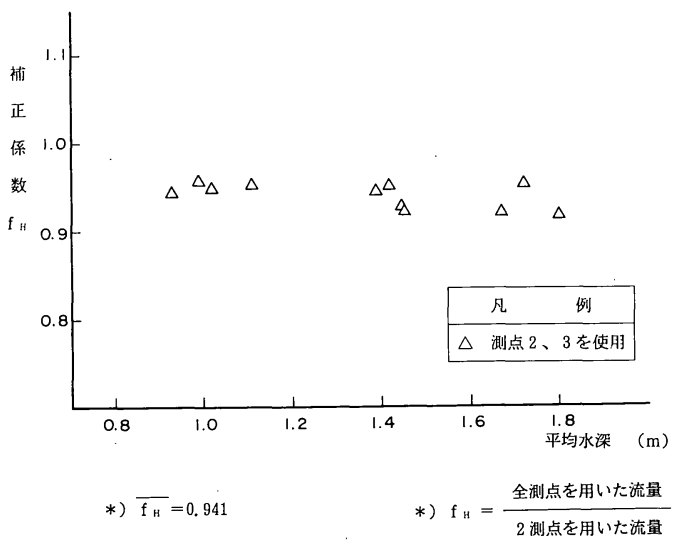

図一 $8 h-f_{H}$ (2 測点)

水深（水位）の増加とともに $\bar{V} / V_{s}$ が増加する事を裏付 けている.

$f_{H}: f_{H}$ については, $V_{s}$ として, 1 点のみ, 2 点, 3 点お よび 4 点を採用した場合を検討した. 1点としては，最 大流速と思われる測点 2 を用いて， $f_{H}$ を算出したとこ 万図一7を得た。 $f_{H}=0.884$, ほとんど一定ということ であった. 2 点としては, 測点 2 と 3 , 測点 2 と 4 , 測 点 2 之測点 3,4 の中間点の 3 者で, 加えて 3 点の場合は, 測点 $2 ， 3 ， 4$ を用いて行ってみたが，それぞれほぼ一定 の值を示した．図一8，9にその一部を示す。平均値は それぞれ $f_{H}=0.941 ， 0.917 ， 0.918 ， 0.938$ である。こ こまでは, 測点 1 に流れの代表性が小さいと考えて, 意 識的にはずした結果以上のようなことになった。

最後に 4 点を用いた場合は，それぞれ 4 点が代表する 断面積を図一10に示すように, 測点 1 と 4 が少ししか 分担しない場合 (ケース1) と，相対に大きく分担する 場合 (ケース 3) とに分けて, 計算して見たが (図一11), いずれも $h(=R=A / B)$ とともにわずかに減少する傾 向を示した. 一定と言えないこともない. $f_{H}$ はそれぞ れ 0.954，0.930であった.

$f_{H}$ について考察すれば，本来河川が一般的に広矩形 断面であることを想定すれば， $f_{H} \fallingdotseq 1.0$ でよいのであろ うが, 魚野川は, 弱い放物線型断面之考えてよく,この 観点からは，1.0> $f_{H}>0.9$ であっても妥当と考えられ る. 最後に, 1 点しかも最大流速点で測っている測点 2 のみの場合には， $f_{H}=0.884$ となった.この点は少なく

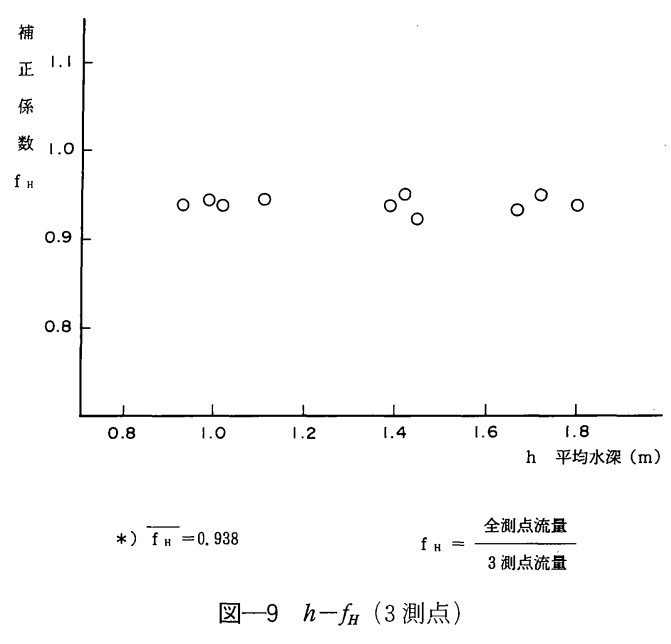

とも観測範囲では最大流速点であり, 横断方向の河床の 影響を受けて，いわば最小值となったのであろう。これ らの $f_{v}, f_{H}$ の数值の性質については, より高い水位での データの集積をまって, 結論を出して行くべきと考えて いる.

$f:$ 最後に $f=Q / \sum^{4}$ であるが, 図一 12 のようになり, わずかに増加傾向, $\bar{f}$ はそれぞれ 0.834 (ケース 1 ), 0.823 (ケース 3 ) であった. しかし, 前述のように測 点 1 が代表性が小さいこともあるので, 例えば $\sum^{3}$ の場 合（测点 $2 ， 3 ， 4 ）$ を対象にして見ると, $f_{H}=0.938 \fallingdotseq$ const, $f_{v}=0.885 \fallingdotseq$ const 故に $f=0.830$ という関係になり，これまで述べて来た観点 から見て, 最もありそうな数值の組合せといえそうであ る.この $f$ は, 魚野川のような融雪出水が期待できない, つまり $\sum^{30}$ などが調查によって容易に得られない河川に とって重要な指標である. 要するに, この $f$ 值は, 魚 野川のような単断面的な河川に対する, $f_{H}, f_{v}, f$ の値 としてほぼ妥当と思われる数值を得ることができたが, 今後, 多様な断面形状の河川での観測結果の集積をまっ て, 水位 (深) 増加にともなう $f$ の特性, 断面形状の差 異にともなう $f_{H}$ の特性など, 確認していく必要があろ う.

\section{（2）補正係数の適用性の検証}

上記の検討によってえられた関係を，91 年 3 月現地 に設置された 4 台の流速計のデータ（つまり図—5の值） を用いて，検証を試みる。ただし

$$
Q=f_{v} \cdot f_{H} \cdot \sum^{1-4} V_{s j} \Delta A_{j} \cos 10^{\circ}
$$

すなわち, 流速計は橋に対して, $10^{\circ}$ 偏角をつけてある ので, $\cos 10^{\circ}$ がかかっている $\left(\cos 10^{\circ}=0.985\right)$.

以下図-13に結果を示す. 左上の図は, $f_{H}, f_{v}$ とも $h$ の関数とした場合, 右上は, $f_{v}=f(h)$ の場合, 左下は $f_{H}$, $f_{v}$ とも平均値を用いた場合, 右下は, 3 点（測点 2,3 , 


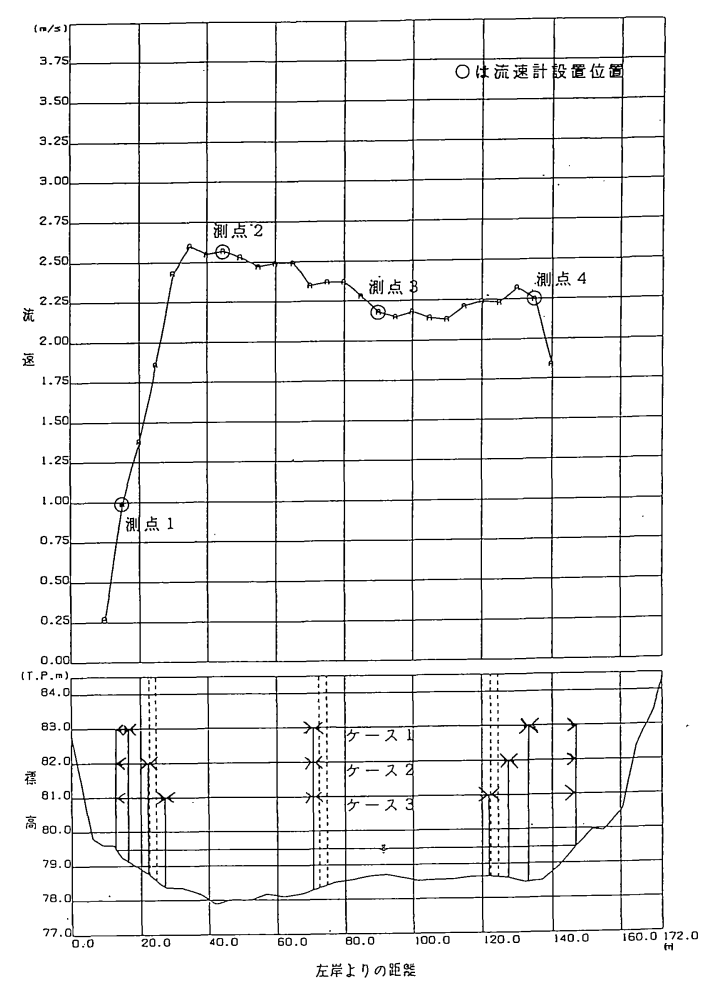

図一10 4 測点観測における流量算定ケースごとの断面の設定

4）のみを利用した場合である.

それぞれ応分の一致度であるが， $\overline{f_{H}}, \overline{f_{v}}$ を用いても， 誤差が小さいことがわかる.ここでは, 観測水位の変化 幅が $1.5 \mathrm{~m}$ であり, もっと範囲がひろがれば，もっと 正確なことがわかろう。

ま亡め: $f_{v}, f_{H}, f$ 值として, $f_{v}=0.85 \sim 0.90, f_{H}=$ $0.92 \sim 0.94$ (测点数 $2 \sim 4$ ), $f=0.80 \sim 0.85$ 等の值は, ほぼ妥当と考えられる值であり, 通常の単断面と考えら れるような河道に対しては，今回のような詳細調查が必 ずしも必要がないことが推定された。これは, 大きな収 穫だったといえる.

本論ひいては解析のいやな点は, 欠点をあげつらった 浮子法による $H \sim Q$ カーブを利用して, 推論を進めて いる点である．例えば，ある地点に新たに流量観測シス テムを設ける場合, 少なくとも $2 \sim 3$ 年は, $H \sim Q$ カー ブの観測の継続が望ましい.

参考までに次に触れる太田川水系古川での調査結果 ${ }^{81}$ でも, $f=0.80$ が応分の一致度を示している（河幅約 40 $\mathrm{m}$, 単断面, 電波流速計 1 台). 因みに $f_{v}=0.85, f_{H}=$ 0.94 とすると, $f=0.80$ となる.

\section{（3） $\boldsymbol{H} \sim \boldsymbol{Q}$ カーブのループ特性}

$H \sim Q$ カーブは, 本質的にはループを描くものであり 一本とみなせるかは, 程度の問題であろう. 実際に浮子 法によっても，ループを観測した例はあるが，電波流速
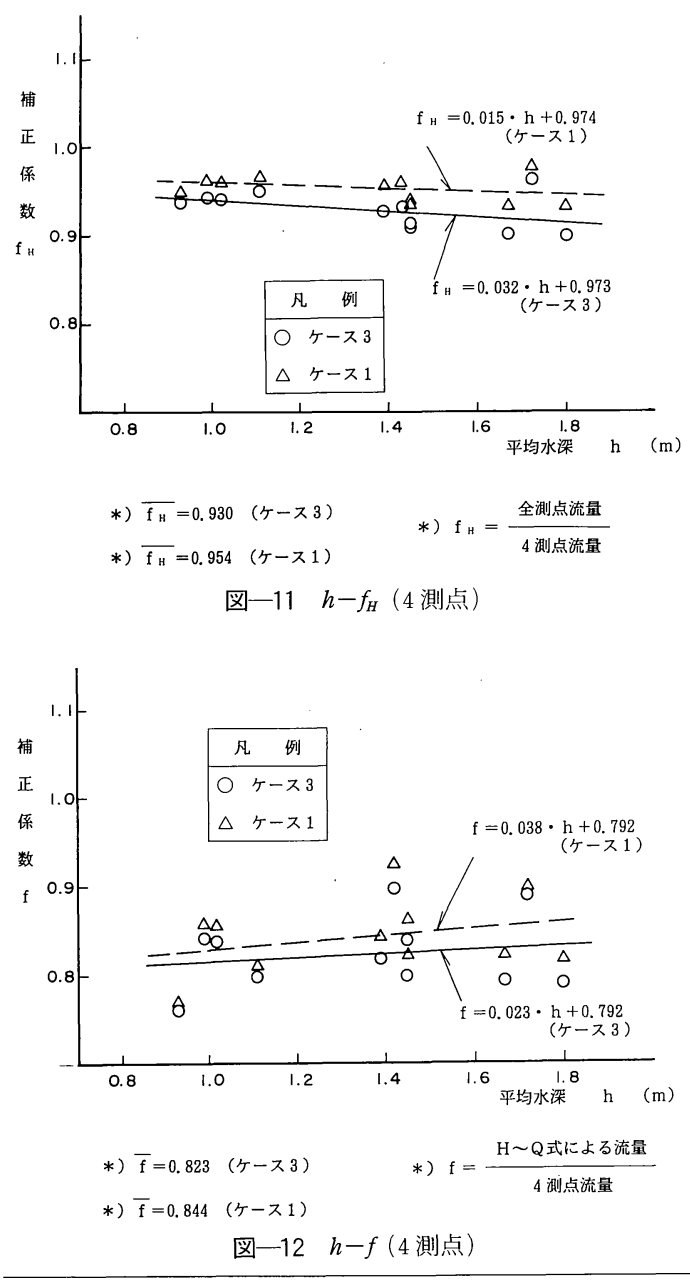

計でも観測することができたので簡単に報告しておく.

観測されたのは，中国太田川水系の古川の松原橋で， 広島市内にあり, 流域は現在急速に都市化が進行してい る (約 $\left.70 \mathrm{~km}^{2}\right)$. 松原橋地点は, 河幅が $40 \sim 50 \mathrm{~m}$ のほ ぼ単断面の河道であり, 電波流速計が 1 台橋のガーダー に設置されて連続観測を行っている(写真一2).ループ の 1 例を図一14に示す。ほかの例については，文献"な どを参照にされたい. 図一 14 上図は $H \sim V$, 下図には, $Q=0.8 V A$ より $Q$ を求めて, $H \sim Q$ が示してある. $H$ 〜Vの大きなループ, $H \sim Q$ についても, 例えば水位 $2.0 \mathrm{~m}$ のとき, 上昇時は, $Q=90 \mathrm{~m}^{3} / \mathrm{s}$, 下降時には, $Q$ $=65 \mathrm{~m}^{3} / \mathrm{s}$ と $30 \%$ も小さなる. このループ特性は, 古川の上流部安川が急勾配なため流出が早く, 太田川の 旧河道である古川に入って緩勾配になることもあって， 古川の河道上流に貯留されて, 下流に向かって水面勾配 がついた結果，このような流速差が発生したものと考え られる.いずれにしてもこのような河川では, $H \sim Q$ カー ブで対処すべきではなかろう．またこれは，都市河川で は，多かれ少なかれ起こっている現象と予想される．な 

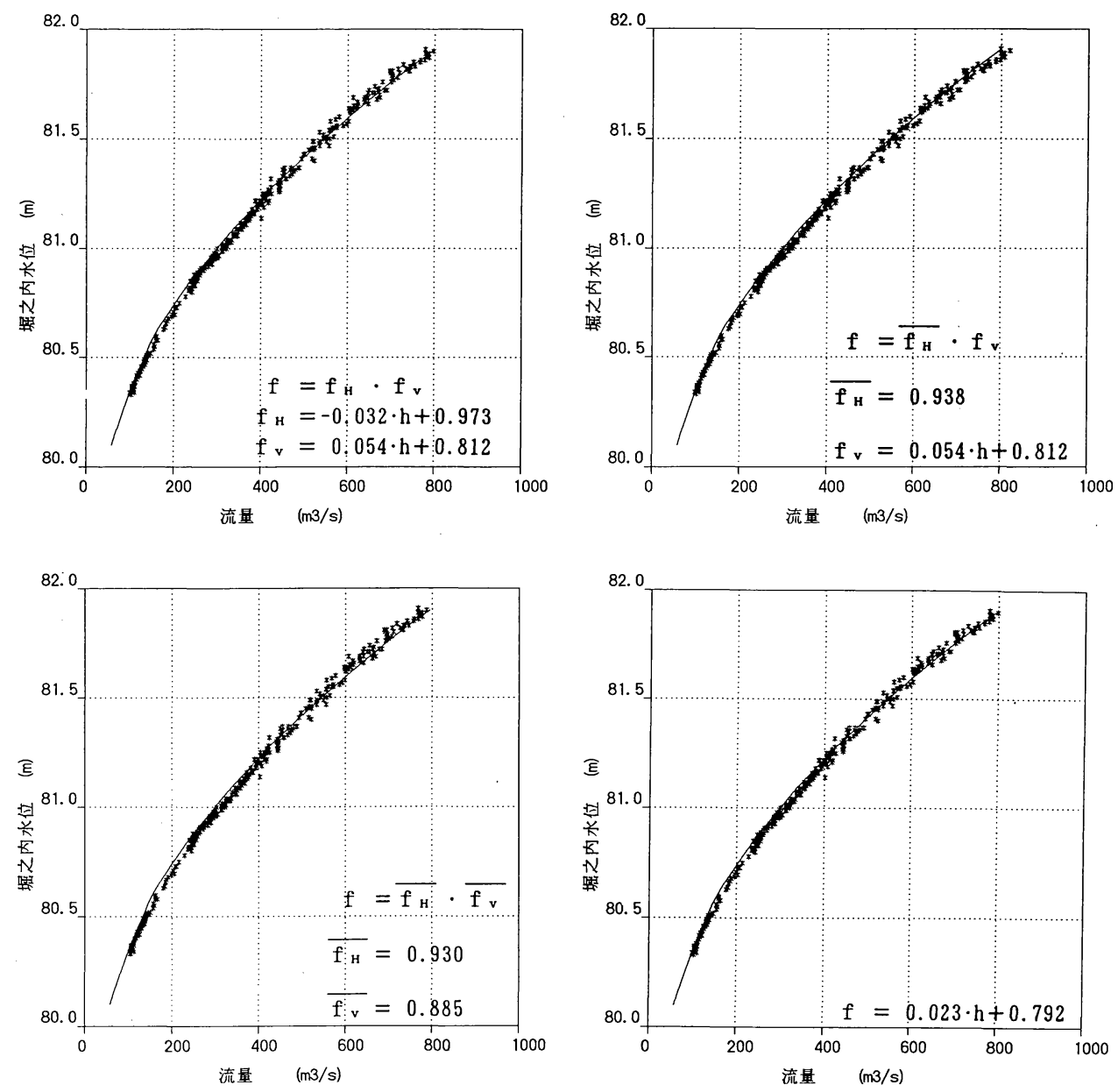

図-13 $H \sim Q$ カーブとの比較

お，このようなときの鉛直方向流速分布がどうなってい るかの問題もあり， $f=0.80$ 一定でよいかは残された問 題であろう. 古川の場合, 流域が小さく, 到達時間が短 いため, 流量観測が水位下降時に行われることが多いが, これはともすると流量の過小評価につながると考えられ る.

\section{（4）偏角をもった観測（含む流向観測）}

a) 偏角をもった観測

橋のような横過構造物のないところで, 岸から流速が はかれないか, 橋がスキューにかかっている場合はどう か, という問題がある. 魚野川の根小屋橋も $10^{\circ}$ ほどス キューであったので，橋に直角に打った場合と $10^{\circ}$ 偏角 をもたせた場合の比較を行い，問題がないことを確かめ $た^{10)}$.

ここでは，偏角をもつと大きくした場合の結果につい て報告する. 利用した水路は, 大井川左岸の用水路で, ほとんど一定流量が流れている(約 $33 \mathrm{~m}^{3} / \mathrm{s}$, 水路幅 9 $\mathrm{m})$. この水路で浮子との検証も行っている (表一1).
観測は, 図一15に示すように, 両岸より偏角を変えて 同一地点を打っている. 観測条件および結果を表一3に 示す. $\mathrm{A}^{\prime}$ 点の流速は $3.23 \mathrm{~m} / \mathrm{s}, 2.5^{\circ}$ 右岸よりの流向亡 いうことがわかっているが，それはすべて右岸側の測定 值が大きいことでもわかる. それ故補正值は, 右 $2.5^{\circ}$ までの偏角を用いて計算してある。この結果より，30 程度の偏角までは, 河岸より河川法線方向の流速は河岸 1 点のみからでも相当の精度で測定できることがわか る. 流向をとらえるためには, 少なくとも河岸 2 点から とらなければならない. $10 \%$ 程度の誤差を許せば $40^{\circ}$ 程度まで可能であろう. 参考までに, 下流橋梁 3 点より 図一15中 B， C, E 点の観測結果を用いて，作図法で 3 点からそれぞれ流速べクトルを求めたものを図一16に 示す. 2 点からの垂線の交点が, 流速ベクトルの推定值 になるが，ほとんど一点近傍に集中している．偏角の中 に $31.2^{\circ}, 57.1^{\circ}$ が入っているが，そ机ほど誤差は与え ていない。また，流向が $\mathrm{B}, \mathrm{C}, \mathrm{E}$ と徐々に，右岸寄り になっていくことがわかる. 


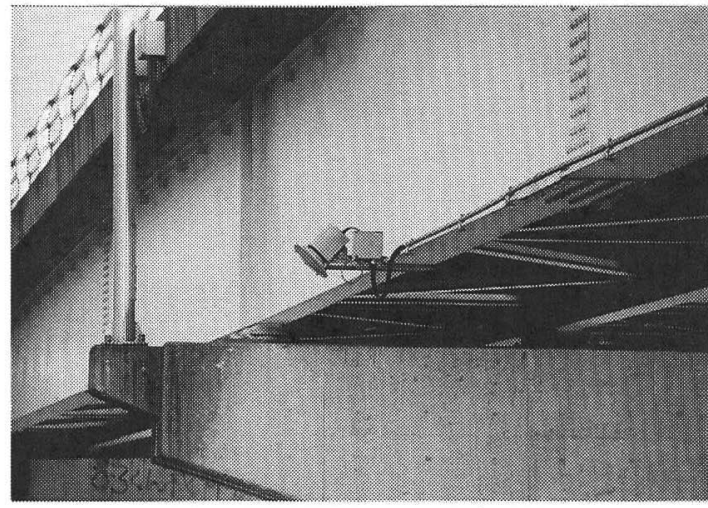

写真一2 古川松原橋の電波流速計
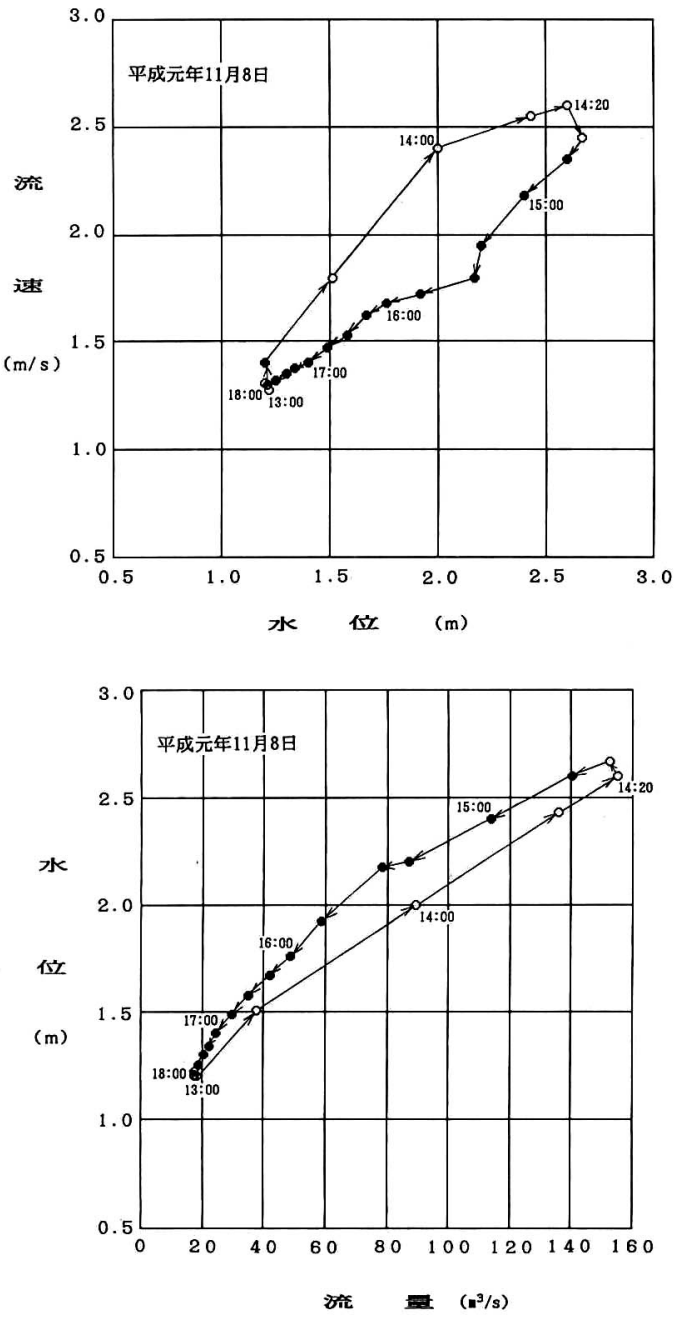

図一14 $H \sim V$ および，Q〜H図（古川）

b) ピア一後流域の観测

前に触れたように，ピア一後流域は，相当にピアーの 影響を受けて, 流速が減少する.これは, 1990 年 3 月

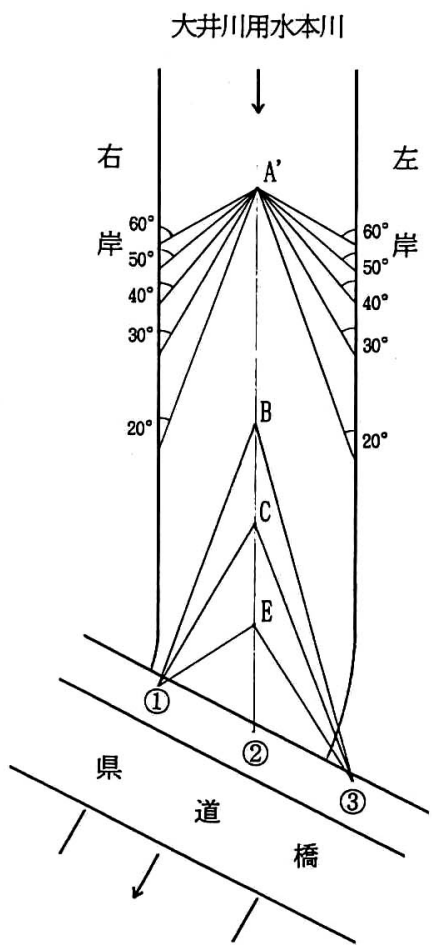

図一15 偏角をもった観測位置平面

表一3 観測値（用水路）

\begin{tabular}{|c|c|c|c|c|c|c|}
\hline 右 & 角 & $20^{\circ}$ & $30^{\circ}$ & $40^{\circ}$ & $50^{\circ}$ & $60^{\circ}$ \\
\hline 岸 & 伤 角 & $13.3^{\circ}$ & $17.7^{\circ}$ & $22.3^{\circ}$ & $26.2^{\circ}$ & $28.6^{\circ}$ \\
\hline よ & 測 定 值 & $2.97 \mathrm{~m} / \mathrm{s}$ & $2.73 \mathrm{~m} / \mathrm{s}$ & 2. $43 \mathrm{~m} / \mathrm{s}$ & $2.16 \mathrm{~m} / \mathrm{s}$ & $1.76 \mathrm{~m} / \mathrm{s}$ \\
\hline$\eta$ & $\begin{array}{l}\text { 補 正 値 } \\
\text { (偏角、侑角) }\end{array}$ & $3.16 \mathrm{~m} / \mathrm{s}$ & 3. $26 \mathrm{~m} / \mathrm{s}$ & $3.40 \mathrm{~m} / \mathrm{s}$ & $3.66 \mathrm{~m} / \mathrm{s}$ & 3. $76 \mathrm{~m} / \mathrm{s}$ \\
\hline 左 & 角 & $20^{\circ}$ & $30^{\circ}$ & $40^{\circ}$ & $50^{\circ}$ & $60^{\circ}$ \\
\hline 岸 & 角 & $12.4^{\circ}$ & $17.7^{\circ}$ & $22.3^{\circ}$ & $26.2^{\circ}$ & $28.6^{\circ}$ \\
\hline 上 & 測 定 値 & $2.86 \mathrm{~m} / \mathrm{s}$ & $2.58 \mathrm{~m} / \mathrm{s}$ & 2. $09 \mathrm{~m} / \mathrm{s}$ & 1. $88 \mathrm{~m} / \mathrm{s}$ & $1.47 \mathrm{~m} / \mathrm{s}$ \\
\hline b & $\begin{array}{l}\text { 補 正 值 } \\
\text { (偏角、俯角) }\end{array}$ & $3.20 \mathrm{~m} / \mathrm{s}$ & $3.23 \mathrm{~m} / \mathrm{s}$ & $3.05 \mathrm{~m} / \mathrm{s}$ & 3. $32 \mathrm{~m} / \mathrm{s}$ & $3.64 \mathrm{~m} / \mathrm{s}$ \\
\hline
\end{tabular}

の根小屋橋下流側の $5 \mathrm{~m}$ 間隔の観測にも認められた（図 省略 $)^{10 !}$. そこで, 左岸から 3 番目のピアー下流部につ いて，測点を $2.5 \mathrm{~m}$ おきに設け（图一17），俯角を 3 種 変え, 1 地点を $5 \mathrm{~m}$ ずつはなれた 3 点からうつ方法で各 点のベクトルを求めて見た．例えば，0点前方 $10 \mathrm{~m} の$ 地点は, 俯角 $45^{\circ}$ にして $L 5,0, R 5$ から同一点を打っ ている. ベクトルの方向が違うので，つなぐべきではな いが，わかりやすくするためにつなぐと図一17が得ら れる. 前述のように, 橋がスキューなためもあうて, 流 速の遅い部分が右岸側にずれていくのがわかる.因みに, 3 点から測っているのは, 2 点からのみでは, 解が $1 つ$ なので，確認の意味も含めてとっている. 

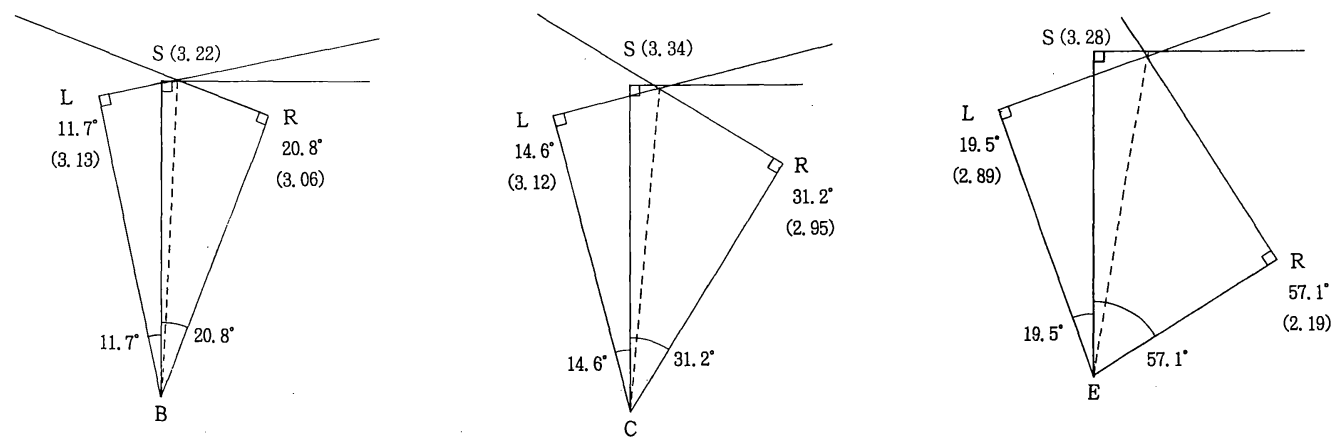

図-16 B，C，E点のベクトル合成図

\section{5. 結 論}

以上の結果より,

a) 固定した数台の電波流速計による表面流速の観測 值に妥当な補正係数を適用することにより, 精度数\%以 下で, 流量が得られる.

b) 補正係数は, 魚野川に対しては, $f_{v}=0.85 \sim 0.90$, $f_{H}=0.92 \sim 0.94, f=0.80 \sim 0.85$ 等が得られたが,これは， ほぼ妥当な值と思われる.なお，古川についても $f=$ 0.80 が得られている.

c) 洪水時の $H \sim V$, ひいては $H \sim Q$ のループ特性が 観測されたことから, 都市河川等 $H \sim Q$ のループ特性 が予想される河川,あるいは非定常特性の強い河川では, 本法の採用が望まれる.

d）河岸等から偏角をもった観測は，30程度までは 十分な精度で可能なことがわかった。

e）流向観測も, 水面 1 点を橋上 2 ないし 3 点から観 測することにより, 流速ベクトルが得られることがわ かった.

f）電波流速計の観測方向, 上流加流かは, 後流域 の再確認により, また, 台数をへらす意味からも, 上流 が相対には好ましいことがわかる. この場合至近の水位 計の位置が問題になるが, 原則としては, 超音波水位計 などを流量観測専用に設けるべきと考える.

\section{6. 今後の方向}

最近, 電波流速計の河川への採用が, 徐々に進みつつ あるが，今後，以下のようなことが望まれる.

a）洪水の始めから終わりまで, 連続的にオンライン でデータが得られることから, 多くの地点で, 採用され ること.

b) 種々の断面形状で, 流量換算係数 $f$ の特性が明ら かにされていくこと.

c）今後設置を計画される方には，できることなら， 必要と思われる台数の倍ほど設置いただき, 数年間きめ の細かい観測を行って, その地点の特性を把握してのち,
下流側ピア付近データ 91. 4.8 堀之内水位 $81.70 \mathrm{~m}$

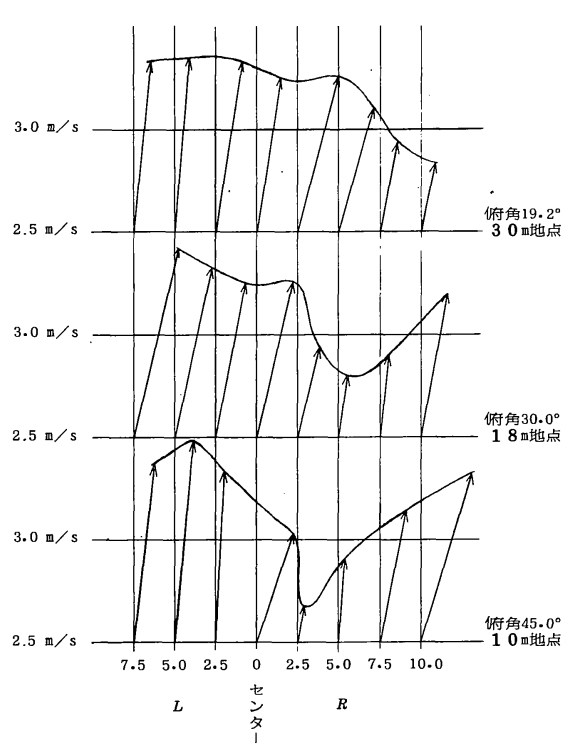

図一17 ピアー後流域ベクトル平面

余分なものを他河川に設置換えするのも, 河川水理学の 発展につながると考える. 大量データが得られると, 水 位毎での流向変化なども読みとることができる．また， 個々の点の $H \sim V$ 関係の変化から, 河床変化も読みとれ るようになると考えられる. 可搬式電波流速計による洪 水時実測による補完も，もう一つの方法である.

d）電波流速計が，急流に向いていることから，ダム 上流部の流入河川に設置する方法について検討したい.

e）表面流速であるから，当然風向風速の影響を受け る. 魚野川については, 一応の補正法を用いてはいるが, データの集積をまって, 完全なものにしていかなければ ならない。

\section{謝辞}

この一連の調査のキッカケを作って頂いた, 建設省河 川局治水課, 土木研究所水文研究室, 中国および北陸地 
建の方々に心からの謝辞を申し上げたい。また，図表等 の作成について五十嵐剛君（河川情報センタ一研究員）

に盡力いただいた。同よう感謝の意を表したい.

参 考 文 献

1）木下良作：航空写真による洪水時の流況測定，水工学シ リーズ68〜12, 1968.

2）木下良作：航空写真による洪水流解析の現状と今後の課 題, 土木学会論文集 345 号, 1984.

3）建設省利根川下流工事事務所・河川情報センター：利根 川下流部流量把握方法検討業務委託報告書, 1992 .

4）吉川秀夫・佐々水六造・仲村 学：上昇気泡による流量 測定のための基礎的研究，土木学会第 47 回年次学術講演 会論文集，pp. 318～319， 1992.
5）建設省：河道特性に関する研究，第 41 回建設省技術研究 会論文集, pp. 58～67, 1987.

6）建設省水文研究会：水文観測，p. 167 , （社）全日本建設 技術協会, 1985 .

7）土木学会：水理公式集, pp. 12 13, (社) 土木学会, 1985.

8）.山口高志：太田川水系古川および安川水文資料, 河川情 報センター, 1991 .

9）山口高志ほか：電波流速計を用いた洪水流量観測システ ムに関する調查, 河川情報研究所報告第 5 号, pp. 91 113, 1991.

10）山口高志ほか：電波流速計を用いた洪水流量観測システ ムに関する調查, 河川情報研究所報告第 4 号別冊一 2 , 1990.

(1993.7.6 受付)

\section{FLOOD DISCHARGE OBSERVATION USING RADIO CURRENT METER}

Takayuki YAMAGUCHI and Kunio NIIZATO

Radio current meters, which are installed on bridges or similar locations, emit radio waves at the surface of the river water and measure the surface velocity from the reflected waves using the Doppler effect. Fieldtest of Radio current-meter has been done on the Uono river for flood discharge measurement during snowmelt flood seasons in 1990 and 1991. In addition, 4 radio current-meter were set on the same bridge in 1991. All of the data were analysed and the estimation method of discharge from surface velocity data obtained, was proposed. The flow velocity and its direction (velocity vector) at a given point can also be obtained from the observation of the water surface at the point from two points on a bridge. Rooping characteristics of $H \sim Q$ relation could be measured on the Furu-River. 